Doi: https://doi.org/10.31578/jebs.v6i2.238

\title{
Development of Soft Skills While Teaching English to Master's Students
}

\author{
Natela Doghonadze* \\ Marina Zoranyan**
}

\begin{abstract}
Besides the knowledge and skills directly related to the profession, the so-called soft or transferable skills are essential for future specialists in all areas. Soft skills involve communication, problem-solving, decision-making, computer, leadership, teamwork, critical and creative thinking, presentation, reflection and other skills, which help people to be employed and develop a successful career. To develop these skills while teaching English at University the following activities are useful: projects, presentations, discussions, debates, keeping portfolios, writing reflective diaries, role play and business games. Mixed paradigm was applied: a quantitative research (self-assessment questionnaire survey) with $60 \mathrm{MA} / \mathrm{MS}$ students and, for triangulation, a focus group interview (a qualitative approach) with 6 of those respondents who volunteered to take part in it. The goal of the research was to find out whether activities supporting the development of soft skills were applied in MA/MS English classrooms and whether the respondent students realized their usefulness for their future career. Two corresponding research questions were asked. The research held applied a researcher-made Likert-scale questionnaire and a focus group interview. The questionnaire was validated and piloted. The interview asked the same questions, trying to get students' insight on the issue. A conclusion was made that presentations, discussions and debates, as well as role play were often applied in their classes, while portfolios, diaries and business games were more or less applied and projects were almost not used. However, the students realized the importance of these activities for their future career.
\end{abstract}

Keywords: soft skills, teaching English as a foreign / second language (EFL, ESL), activities, Master's students

\section{Introduction}

We live in the era of advanced technologies and rapid economic development. Due to it, having professional knowledge is necessary but insufficient for being employed and maintaining the job. Musa et al. (2012) claim that the "21st century employers are looking for graduates who possess soft skills that include responsibility, self-confidence, social and communication skills, flexibility, team-spiritedness, good work attitude, self-motivation and self-management" (p. 565).

Compared to hard skills directly related to profession, soft skills, according to Cimatti (2016), are those skills that are not related directly to a specific task fulfilled at work, but are linked with the job in general and concern relationships with people (colleagues and clients). She divides them into two categories: self-oriented (cognitive) and other-oriented (social) skills. Cognitive skills involve critical judgment and planning skills, while social skills involve communication, negotiation, networking, problem solving and decision making. Cinque (2015) cites Nobel 2000 prize winner's James Heckman's words that success in life depends

\footnotetext{
* International Black Sea University, Tbilisi, Georgia, ORCID id 0000-0001-7333-8692

** Georgian Technical University, Tbilisi, Georgia,

Coresponding Email: nateladoghonadze@ibsu.edu.ge, marinaziger@gmail.com
} 
on soft skills otherwise called life skills, transversal skills, generic competences, the $21^{\text {st }}$ century skills, etc. Dean and East (2019) state that hard skills are no longer sufficient in highly competitive global environment. Therefore, teaching them at higher education institutions is indispensable.

The benefits of soft skills include increased confidence, managing and developing self and tasks, better performance in interviews, better work performance, ability to apply numeracy; increased emotional intelligence, autonomy, and holistic growth (Meeks, 2017; Petiz Pereira \& Costa, 2017; Tsey et al., 2018; Wats \& Wats, 2009; Wheeler, 2016). Tripathy (2020) formulated the role of soft skills as follows: "Soft skills are in fact healthy supporters of communication and performance. They are recognized as connectors that build the gap and bridge relationships among people at the workplace, leading to better productivity and performance" (p.1).

Globalization is one of the major phenomena inherent in modern society and embracing all the spheres of our lives. It is an irreversible process of economic, social, political and cultural integration. Globalization has interconnected people all over the world and created opportunities for them to live, study, work and communicate with each other. In connection with this the need in a global language as the means of intercultural communication between people from different countries and different cultural backgrounds has arisen. Taking into consideration geographical and social-cultural factors, the English language has acquired a global status and has become the language of intercultural communication. Nowadays, a good command of English is recognized as an indispensable part of many professions and occupations. That is why, while teaching English at university, it is necessary to develop both language and soft skills, because they are just as important for the graduates' future careers. Teaching English in the $21^{\text {st }}$ century is aimed at mastering intra- and interpersonal skills or, in other words, the so-called soft skills that are vital for personal development, social participation, and workplace success. These skills can also influence our ability to navigate through life successfully and effectively. Soft skills can be efficiently taught at universities if integrated into curricula and syllabi. Besides, special seminars, coaching and tutoring also have their role in developing these skills in students of various faculties and programs. While embedded in a particular course, in our case, English as a Foreign Language (EFL) or English for Specific Purposes (ESP), they can be taught through particular activities such as project work and teamwork.

The background of the research was the second cycle of higher education in Georgia on the example of Masters' students at Georgian Technical University. Foreign language (especially, English) is a compulsory course in Georgian higher education institutions. The goal of the research was to find out whether activities supporting the development of soft skills were applied in MA/MS English classrooms and whether the respondent students realize their usefulness for their future careers.

\section{Theory / Literature Review}

Whereas the education of the past was oriented on knowledge, since the 1970s, education has emphasized the need in skills. One of the first publications on the issue was the report Learning to Be (Faure et al., 1972). Later, Friedman (2006) was the first to discriminate between soft and hard skills.

The Oxford Advanced Learner English Dictionary (OALED, 2019) defines soft skills as "personal qualities that enable someone to interact well with other people;" they involve team work, enthusiasm, and emotional intelligence. Soft skills are necessary for everyday life. They are vital for interaction between people and building good relationships with them. Soft skills include attitude, adaptability, communication abilities, creative thinking, teamwork, decision making, motivation, problem-solving, critical thinking, presentation skills, active listening, observing work ethic, emotional intelligence, and reflection. Soft skills are just as important as professional skills and they can develop through education and experience. 
According to Musa et al. (2012), soft skills include "communication skills, problem-solving skills, computer literacy, information literacy, ability and willingness to learn, and teamwork" (p.565). Direito et al. (2012) mentioned that they involve "information literacy, ability and willingness to learn, and teamwork" (p. 844). Pachauri and Yadav (2014) defined soft skills as "personality traits, social gracefulness, fluency in language, personal habits, friendliness, and optimism to varying degrees" (p.22).

Soft skills help people to adapt to environment, especially to workplace (Kechagias, 2011). Patacsil and Tablatin (2017) emphasized the role of IT skills among the soft skills, as any profession nowadays requires searching information on the internet as well as using computer and mobile devices for communication. Team work is also often done via IT. Glaittli (2018) provides a long list of soft skills including "adaptability, critical thinking, empathy, integrity, optimism, problem solving, decision making, goal setting, self-advocacy, proactivity, resilience, grit, teamwork, self-motivation, communication, positive attitude leadership, independence, self-regulation, creativity, time management, organization, professionalism in dress, work ethic, and punctuality" (p.4). Hodges and Burchell (2003) in their study of 52 different professions held with more than 8,000 American administrators enumerate as top soft skills learning, communication, and problem-solving skills.

It is visible that, although different authors give different definitions to soft skills and include different skills in the list, there is a certain common understanding on the issue. In the given article soft skills will be viewed as communication, problemsolving, decision-making, computer, leadership, teamwork, critical and creative thinking, presentation, reflection and other skills, which help people to be employed and develop a successful career.

As communication skills are among the most important soft skills, and communication in English is essential nowadays, special attention is paid to English language teaching to MA/MS students. In Georgia, for example, one cannot be admitted to master studies unless he/she possesses the B2 level of English skills (National Center for Educational Quality Enhancement, 2019).

According to Council of Europe (2001), communicative competence involves the following components: linguistic, sociolinguistic and pragmatic competences (p.108). In turn, linguistic competence includes: lexical, grammatical, semantic, phonological, orthographic and orthoepic competences (p. 109); sociolinguistic competence "is concerned with the knowledge and skills required to deal with the social dimension of language use" (p. 118) and pragmatic competence deals with the person' s knowledge of utterance organization and structure and communicative functions (p. 123). Correspondingly, while teaching a language, we, voluntarily or not, provide the development of communicative competence. Besides, while teaching a foreign/second language we develop problem-solving (decision-making), computer, leadership, teamwork, critical thinking, presentation, reflection skills through reading/writing projects, preparing and delivering by students of power point presentations, discussions, debates, keeping portfolios, writing reflective diaries, role play and business games (Abd Azis, \& Vaidez, 2016; .Harizaj, \& Hajrulla, 2017; Rani, 2017; Rao, 2019). Thus, for instance, problem solving skills are developed via project activities, discussions and debates, as well as business games. On the other hand, such an activity as student presentations requires computer, information seeking, critical, creative thinking and presentation skills. See the relationships between language learning activities and soft skills in Table 1. A cross $(x)$ is put where the activity meets a certain soft skill. 
Table 1. Relationships between language learning activities and soft skills

\begin{tabular}{|c|c|c|c|c|c|c|c|c|c|}
\hline \multirow{2}{*}{$\begin{array}{l}\text { activities/ } \\
\text { soft skills }\end{array}$} & \multicolumn{3}{|c|}{ communicative competence } & \multirow{2}{*}{$\begin{array}{l}\text { problem- } \\
\text { solving \& } \\
\text { decision- } \\
\text { making }\end{array}$} & \multirow{2}{*}{$\begin{array}{l}\text { computer } \\
\text { (IT) }\end{array}$} & \multirow{2}{*}{$\begin{array}{l}\text { leadership } \\
\& \\
\text { teamwork }\end{array}$} & \multirow{2}{*}{$\begin{array}{l}\text { critical } \\
\text { and } \\
\text { creative } \\
\text { thinking }\end{array}$} & \multirow[t]{2}{*}{ presentation } & \multirow{2}{*}{$\begin{array}{l}\text { reflection } \\
\text { (analysis) }\end{array}$} \\
\hline & linguistic & $\begin{array}{l}\text { socio- } \\
\text { linguistic }\end{array}$ & pragmatic & & & & & & \\
\hline project & $\mathrm{x}$ & & $\mathrm{x}$ & $\mathrm{x}$ & $\mathrm{x}$ & $\mathrm{x}$ & $\mathrm{x}$ & $\mathrm{x}$ & $\mathrm{x}$ \\
\hline Presentation & $\mathrm{x}$ & $\mathrm{x}$ & & & $\mathrm{x}$ & & & $\mathrm{x}$ & \\
\hline $\begin{array}{l}\text { discussion } \\
\& \text { debate }\end{array}$ & $x$ & $\mathrm{x}$ & & $x$ & & & $x$ & & $\mathrm{x}$ \\
\hline portfolio & $\mathrm{x}$ & & & & $\mathrm{x}$ & & & & \\
\hline diary & $\mathrm{x}$ & & & & $\mathrm{x}$ & & $x$ & & $\mathrm{x}$ \\
\hline role play & $\mathrm{x}$ & $\mathrm{x}$ & $\mathrm{x}$ & & & & $\mathrm{x}$ & $\mathrm{x}$ & \\
\hline $\begin{array}{l}\text { business } \\
\text { game }\end{array}$ & $x$ & $\mathrm{x}$ & $x$ & $x$ & & & & $\mathrm{x}$ & \\
\hline
\end{tabular}

(Developed by the researchers)

\section{Methodology and method}

According to Cohen et al. (2018),

Methodology concerns how we find out about the phenomenon, the approach to be used, the principles which underpin it and the justification for using the kind of research approach adopted, the type of study to be conducted, how the research is undertaken (with its associated issues of kinds of research, sampling, instrumentation, canons of validity etc.). (p. 186).

Correspondingly, the methodology of the current research is based on positivist ontology (Realism - emphasizing the objectivity of the research), objectivist epistemology (applying on empirical data) and axiology (ethics, which will be viewed below).

The theoretical framework for the current research is based on Bandura's (1986) Social Cognitive Theory, according to which knowledge is developed by observing others and imitating them, learning from them. The English language teaching theoretical basis is Communicative Language Teaching (CLT), an approach to language teaching that emphasizes communication both as the goal and the means of teaching. Its typical activities are role plays, interviews, group work, information gap, and opinion sharing (Richards \& Rogers, 2014). These activities are shown in the article as the activities developing, besides language skills, soft skills.

The current research is based on mixed methodology: it applies a descriptive (non-experimental quantitative) method survey and a focus group questionnaire (qualitative research tool). According to Kapur (2018), the goal of surveys "... is to discover the relative incidence, distribution and interrelations of sociological and psychological variables. Survey research is mostly devoted 
to the study of characteristics of the populations under investigation" (p.17). As for focus groups interview, it, according to Cohen et al. (2018), has "the attraction of synergy, with several people stimulating discussion and working together on the issue in hand (p. 532)."

\subsection{Research problem and questions}

While the majority of employers expect the employees to possess an effective mix of hard and soft skills, students often do not realize the need to have soft skills into their curricula and syllabi (Porter, 2007). As students as stakeholders participate in program assessment, it is crucial to investigate the situation in the country and particular institutions in order to bring the programs in correspondence with market demands.

The question whether soft skills were developed in Armenia, Azerbaijan, Bolivia, Colombia, Georgia, Ghana, Kenya, Laos, Macedonia, Sri Lanka, Ukraine, Vietnam and Yunnan Province in China was studied by the World Bank (2014). Both the research in Georgia (World Bank, 2013) and in other countries showed that, although soft skills are to a certain level developed, they constitute a serious obstacle to effective work in companies.

The study by Majid et al. (2012) revealed that only some soft skills (communication, leadership, persuasion and negotiation skills) were chosen by all respondents in their study as necessary ones, and only $21 \%$ of students chose all soft skills offered for their attention. Glaittli (2018) found that students are aware of the need in soft skills, but are reluctant to hold the relevant activities on a regular basis.

To tackle this problem and to find out whether the situation in Georgian higher education institutions has recently improved two research questions were asked:

- Are the activities for the development of soft skills applied during EFL / ESP classes?

- How do you rate the given activities?

\subsection{Research tools}

The tool for the survey, the questionnaire, in order to answer the research questions, asked the participants to assess according to a 5-point Likert scale the application in their class of and their views on particular activities (projects, presentations, discussions and debates, portfolios, diaries, role play and business games). Before using it for research purposes, in order to make the research results reliable, it was piloted with $10 \mathrm{MS}$ students who further were not involved in the research. After piloting, short definitions of each activity were added to the instruction part of the questionnaire by the students' recommendation, to provide a clear understanding of the respondents and to avoid misunderstanding). The questionnaire items were assessed according to face, construct and content validity by three external experts in the field.

Two research questions were asked, correspondingly, the students had to assess the items (activities) from two viewpoints: whether they were applied at their English classes (never - 1 point, seldom - 2 points, the respondent does not have a clear opinion - 3 points, often - 4 points, and very often - 5 points) how useful they find the given activities in their future work ( 1 - not useful at all, 2 - of little value, 3 - the respondent does not have a clear opinion, 4 - useful, 5 - extremely useful).

For the focus interview the grand-tour question was: 'Please tell about the activities applied in your English classes and how useful they were for your future profession.' The sub-questions enumerated the activity types, e.g., 'Did you make up portfolios?' or 'Do you think portfolios are useful for your future employment?' To make it clear what exactly the researcher was 
interested in probes (paraphrases) were used such as 'Do you mean that projects and discussions are more useful than other activities?'

\section{Procedure}

The questionnaire was held in December 2019. It was delivered to Master's students after classes and took just five minutes of their time. Participation was voluntary. The students were explained that the obtained results would be anonymous and would not be used against them in any way. The statistic measures of means and standard deviation were calculated with 21 software. The obtained results were analyzed. The interview was transcribed, the answers underwent content analysis, and most informative answers were selected.

\subsection{Population and Participants}

Among the 148.8 thousand higher education students in Georgia in academic year 2019/2020 about 20,000 are Master's students (Geo.stat, 2021). The respondents represented three from 29 MA / MS programs delivered at Georgian Technical University, one of the largest universities in Georgia. The programs and the students, to make the research representative for the given university, were selected at random (on condition that the chosen candidate accepted to participate). This enabled the researchers to claim that the obtained results are generalizable for the given university. Totally 60 students took part in the research.

\subsection{Analysis of Results}

The questionnaire results (means and standard deviations calculated via SPSS21 software) are presented in Table 2.

Table 2. Research results

\begin{tabular}{|l|l|l|l|l|l|l|l|l|l|l|l|l|l|l|}
\hline & \multicolumn{3}{|c|}{ The activities applied at their English classes } & \multicolumn{3}{|c|}{ The activities will be useful in their future work } \\
\hline & 1 & 2 & 3 & 4 & 5 & mean & st.dev. & 1 & 2 & 3 & 4 & 5 & mean & st.dev. \\
\hline Projects & $30 \%$ & $45 \%$ & $0 \%$ & $25 \%$ & $0 \%$ & 2.20 & 1.15 & $0 \%$ & $0 \%$ & $0 \%$ & $25 \%$ & $75 \%$ & 4.75 & 0.44 \\
\hline Presentations & $0 \%$ & $0 \%$ & $0 \%$ & $35 \%$ & $65 \%$ & 4.65 & 0.49 & $0 \%$ & $0 \%$ & $0 \%$ & $30 \%$ & $70 \%$ & 4.70 & 0.47 \\
\hline $\begin{array}{l}\text { Discussions } \\
\text { and debates }\end{array}$ & $0 \%$ & $0 \%$ & $0 \%$ & $10 \%$ & $90 \%$ & 4.90 & 0.31 & $0 \%$ & $0 \%$ & $0 \%$ & $25 \%$ & $75 \%$ & 4.75 & 0.44 \\
\hline Portfolios & $10 \%$ & $40 \%$ & $10 \%$ & $40 \%$ & $0 \%$ & 2.80 & 1.11 & $0 \%$ & $15 \%$ & $0 \%$ & $60 \%$ & $25 \%$ & 4.10 & 0.64 \\
\hline Diaries & $10 \%$ & $40 \%$ & $10 \%$ & $40 \%$ & $0 \%$ & 2.80 & 1.11 & $0 \%$ & $0 \%$ & $0 \%$ & $75 \%$ & $25 \%$ & 4.25 & 0.44 \\
\hline Role play & $0 \%$ & $0 \%$ & $0 \%$ & $25 \%$ & $75 \%$ & 4.75 & 0.44 & $0 \%$ & $0 \%$ & $15 \%$ & $70 \%$ & $15 \%$ & 4.00 & 0.56 \\
\hline $\begin{array}{l}\text { Business } \\
\text { games }\end{array}$ & $10 \%$ & $40 \%$ & $0 \%$ & $50 \%$ & $0 \%$ & 2.90 & 1.17 & $0 \%$ & $0 \%$ & $15 \%$ & $65 \%$ & $20 \%$ & 4.05 & 0.37 \\
\hline
\end{tabular}

The results revealed that presentations, discussions and debates, as well as role play were often applied in their classes (the mean results, consequently equaled $4.65,4.90$ and 4.74 , while the standard deviations were low - from 0.31 to 0.49 , which shows that 
the students were quite unanimous in their viewpoints). Portfolios, diaries and business games were more or less often applied (the mean results consequently equaled 2.80, 2.80 and 2.90, while the high standard deviation - from 1.11 to 1.17 point to the fact that the students are not unanimous in their answers, which may be explained by different teaching styles of their instructors). Projects were almost not used (the mean result equaled 2.20, while again the high standard deviation - 1.15 - shows that their opinions differed).

Concerning the understanding by the respondent students of the usefulness of these activities for their future profession, the questionnaire results were as follows:

- The respondents were quite unanimous in their answers (the standard deviation is $0.37-0.56$ )

- They realized that all activities are useful for their future professional careers (mean 4.0-4.75). They view projects and discussions and debates as the most useful activities for their future jobs (means 4.75).

- Below find some interview answers that confirm the questionnaire findings:

- 'We regularly discussed some news in technologies that we read about on the internet or heard on TV. It was both enjoyable and useful'.

- 'We often had debates on professional topics. It was a good preparation for professional life'.

- 'It's good that the teacher organized debates about technical news. It's more interesting and useful than discussing the texts from the coursebook.'

- 'We made presentations in class dealing with our specialty. It wasn't easy, but helped us gain self-confidence'.

- 'I learn and work. The presentation skills that I've developed at my English lessons have been extremely useful. I've received a promotion'.

- 'Role play enables me to practice for the future job. Although English classes are not my majors, but they prepare my future career.'

- 'Our syllabus included projects, however, the teacher has never offered us to write either individual or group projects'.

- 'I applied the portfolio we developed as homework for my job competition and was hired. It's great!

- 'I think nobody keeps diaries in the $21^{\text {st }}$ century. Even electronic ones.'

- 'Business games were very useful. It's a pity we had them only a couple of times'.

- 'All activities included in the questionnaire enable to develop useful skills, but keeping a diary is boring.'

The interviewees mentioned that they liked their English classes and believed that they were professionally useful. The soft skills developed during the English lessons contribute to the skills of MA students' majoring in technical sciences.

\subsection{Discussion}

Anthony and Garner (2016) found that many employers lack soft skills in their employees. Pezer (2015) emphasized that soft skills are essential not only for students majoring in humanities and business, but also for future engineers. Chavan (2020) stated that the lack of soft skills among employees can even bring business to bankruptcy. World Bank $(2013,2014)$ confirmed the lack of soft skills in numerous countries, including Georgia. Clarke (2016) complained about the lack of soft skills of over half a million UK employees. Majid (2012) stressed the lack of students' awareness of the need of soft skills.

Our findings deal with activities for the development of soft skills, however, it is possible to view our results as being in line with the above researches, as when few activities for soft skills development are used, naturally, the level of the skills cannot be sufficient. For instance, Tsey et al. (2018) underline the need of participatory social learning approach for the development of soft skills, thus, emphasizing the role of classroom activities for their formation. 
Concerning the second research question, our findings are similar to researches dealing with the application of project-based learning (Musa et al., 2012; Ibrahim et al., 2018), making presentations (Meeks, 2017; Vasanthakumari, 2019), discussions and debates (Alcan et al., 2016; Iman, 2017), portfolios (Meeks, 2017; Parker et al., 2020), diaries (Brooman \& Stirk, 2020), role play (Abdul Rahman \& Maarof, 2018), and business games (de Freitas \& Routledge, 2013; Levant et al., 2016) - they all impact the development of soft skills, which makes the findings of the current research, though limited in scale, more trustworthy.

\section{Conclusions and recommendations}

The research has revealed that MA/MS students at Georgian Technical University involved in the research realized that learning English involves activities developing not only language, but also soft skills, which they find useful. They are often suggested fulfilling presentations, taking part in discussions, debates, and role play and sometimes offered to be involved in business games and compose portfolios and diaries. Unexpectedly for students in technical majors, projects were almost not offered to them, while they realize the importance of the activity. It is necessary to recommend to English teachers at Georgian Technical University to apply projects more often. All foreign language teachers worldwide delivering classes at MA/MS level can be recommended to apply student presentations, discussions, debates, role play, portfolios, diaries and business games in order to develop communication, problem-solving, decision-making, computer, leadership, teamwork, critical and creative thinking, presentation, and reflection skills. While many successful MA/MS programs involve in the curriculum and syllabi the hard skills necessary for the given specialty, fewer programs integrate soft skills and recommend particular activities for their development. This gap has to be filled, if higher education institutions want to train the $21^{\text {st }}$ century specialists.

Further research, on national and international scale, is needed concerning the application of soft skills in higher education, linking them to education levels (Bachelor's or Master's), and to majors, as this is essential for graduates employability and their success at work as more and more employers prefer to hire and maintain employees who possess a blend of hard and soft skills, are resourceful, ethical and can carry out effective communication. It is necessary to bring the necessity of soft skills development to policy makers in education, program developers, lecturers and students. Only then their integration will occur not only on paper (program and syllabi descriptions), but also in the educational process. 


\section{References}

Abd Azis, N.H., \& Vaidez, N.P. (2016). Debate as a pedagogical tool to develop soft skills in EFL/ESL classroom: A qualitative case study. Petranika Journal of Social Sciences and Humanities. 24(1), 213-240.

Abdul Rahman, N.A. \& Maarof, N. (2018). The effect of role-play and simulation approach on enhancing ESL oral communication skills. International Journal of Research in English Education, 3(3), 63-71. DOI: 10.29252/ijree.3.3.63

Alcan, E.M., Abd Aziz, N.H., \& Valdez, N.P. (2016). Debate as a pedagogical tool to develop soft skills in EFL/ESL classroom: A qualitative case study. Pertanica Journal of Social Sciences and Humanities, 24(1), 213-40).

Anthony, S., \& Garner, B. (2016). Teaching softs skills to business students: An analysis of multiple pedagogical methods. Business and Professional Communication Quarterly, 79(3), 360-370.

Bandura, A. (1986). Social foundations of thought and action: A social cognitive theory. Englewood Cliffs, NJ: Prentice-Hall.

Brooman, S. \& Stirk, S. (2020). Who am I?: Using reflective practice and self-determination to redefine 'employability' in legal education. Liverpool Law Review, 41, 79-98 (2020). https://doi.org/10.1007/s10991-020-09240-5

Chavan, S.W. (2020). The importance of soft skills. International Journal of Science and Research, 9(5), 623-625.

Cimatti (2016). Definition, development, assessment of soft skills and their role for the quality of organizations and enterprises. International Journal for Quality Research, 10(1) 97-130.

Cinque, M., (November 2015). Comparative analysis on the state of the art of Soft Skill identification and training in Europe and some Third Countries. Speech at "Soft Skills and their role in employability - New perspectives in teaching, assessment and certification", workshop in Bertinoro, FC, Italy.

Clarke, M. (2016). Addressing the soft skills crisis. Strategic HR Review, 15(3), 137-139. DOI:10.1108/SHR-03-2016-0026

Cohen, L, Manion, L., \& Morrison, K. (2018). Research methods in education. $8^{\text {th }}$ edition. London: Routledge.

Council of Europe. (2001). Common European Framework of Reference for Languages (CEFR). Cambridge: Cambridge University Press.

Dean, S. \& East, J. (2019). Soft skills needed for the 21st-century workforce. International Journal of Applied Management and Technology, 18(1), 17-32.

de Freitas, S. \& Routledge, H. (2013). Designing leadership and soft skills in educational games: The e-leadership and soft skills educational games design model (ELESS). British Journal of Educational Technology, 44(6), 951-968. DOI: 10.1111/bjet. 12034

Direito, I., Pereira, A., \& de Oliveira Duarte, A.M. (2012). Engineering undergraduates' perceptions of soft skills: relations with selfefficacy and learning styles. Procedia: Social and Behavioral Sciences. International Conference on New Horizons in Education INTE 2012, 55 (2012), 843 - 851. DOI: 10.1016/j.sbspro.2012.09.571

Faure, E., Herrera, F., Kaddoura, A.D., Lopes, H., Petrovski, A., Rahnema, M., \& Ward, F.C. (1972). Learning to be: the world of education today and tomorrow. Paris: UNESCO.

Friedman, T.L. (2006). The world is flat: the globalized world in the twenty-first century. $2^{\text {nd }}$ edition. London: Penguin Books. 
Geo.stat. (2021). Higher education. Retrieved 12.01.2021 from https://www.geostat.ge/en/modules/categories/61/highereducation

Glaittli, M. (2018). Soft skills in high school. PhD dissertation. Tempe, AZ: Arizona State University.

Harizaj, M. \& Hajrulla, V. 2017. Fostering learner's critical thinking skills in EFL: Some practical activities. European Scientific Journal, 13 (29), 126-133. DOI: 10.19044/es

Hodges, D., \& Burchell, N. (2003). Business graduate competencies: Employers' views on importance and performance. Asia-Pacific Journal of Cooperative Education, 4(2), 16-22.

Ibrahim, M., Al-Shahrani, A, Abdalla, M. Abubaker, I., \& Mohamed, M. (2018). The effectiveness of problem-based learning in acquisition of knowledge, soft skills during basic and preclinical sciences: Medical students' points of view. Acta Inform Med, 26 (2), 119-124. DOI: 10.5455/aim.2018.26.119-124

Iman, J.N. (2017). Debate instruction in EFL classroom: Impacts on the critical thinking and speaking skill. International Journal of Instruction, 10(4), 87-108.

Kapur (2018). Research methodology: Methods and strategies. Delhi, India: University of Delhi.

Kechagias, K. (Ed.) (2011). Teaching and assessing soft skills. Thessaloniki, Greece: MASS Project.

Levant, Y., Coulmont, M., \& Sandu, R. (2016). Business simulation as an active learning activity for developing soft skills. Accounting Education, 25 (4), 368-395.

Majid, S., Liming, Z., Tong, S., \& Raihana, S. (2012). Importance of soft skills for education and career success. Journal for CrossDisciplinary Subjects in Education, Special issue 2 (2), 1036-1042.

Meeks, G.A. (2017). Critical soft skills to achieve success in the workplace. Doctoral dissertation. Minneapolis, MN: Walden University.

Musa, F., Mufti, N., Latiff, R.A., \& Amin, M.M. (2012). Project-based learning (PjBL): Inculcating soft skills in $21^{\text {st }}$ century workplace. Procedia: Social and Behavioral Sciences. UKM Teaching and Learning Congress 2011, 59, 565 - 573.

National Center for Educational Quality Enhancement. (2019). Accreditation Standards for Higher Education Programs. Assessed November 06, 2019 from https://eqe.ge/res/docs/AccreditationStandardsforHigherEducationProgrammes.pdf

OALED: Oxford Advanced Learner English Dictionary (2019). Soft skills. Assessed December 06, 2019 from https://www.oxfordlearnersdictionaries.com/definition/english/soft-skills

Pachauri, D., \& Yadav, A. (2014). Importance of soft skills in teacher education program. International Journal of Educational Research and Technology, 5 (1), 22-25.

Parker, F. \& McMillan, L. (2020). Using e-portfolio to showcase and enhance soft skill reflection of MSN students. Journal of Nursing Education, 59(5), 300. https://doi.org/10.3928/01484834-20200422-16

Patacsil, F. \& Tablatin, C.L. (2017). Exploring the importance of soft and hard skills as perceived by IT internship students and industry: a gap analysis. Journal of Technology and Science Education, 7(3), 347-368. 
Petiz Pereira, O. \& Costa, C.A. (2017). The importance of soft skills in the university academic curriculum: The perceptions of the students in the new society of knowledge. International Journal of Business and Social Research, 7(6), 1-12. DOI: https://doi.org/10.18533/ijbsr.v7i6.1052

Pezer, D. (2015). The importance of soft skills. $7^{\text {th }}$ International Scientific and Expert Conference TEAM 2015: Technique, Education, Agriculture \& Management. Belgrade, October 15-16, p. 75-79.

Porter, J. (2007). B-schools soft on 'soft skills'. Bloomberg BusinessWeek Online. https://www.bloomberg.com/news/articles/200708-02/b-schools-soft-on-soft-skillsbusinessweek-business-news-stock-market-and-financial-advice. Assessed January $13,2021$.

Rani, S. (2017). Soft skills: Need of modern era. International Journal of Applied Research, 3(3), 363-365.

Rao, P. (2019). The need to develop soft skills among the English language learners in the $21^{\text {st }}$ century. Research Journal of English, 4 (2), 286-292.

Richards, J. \& Rogers, T. (2014). Approaches and methods in language teaching (3 ${ }^{\text {rd }}$ edition). Cambridge: Cambridge University Press.

Tripathy, M. (2020). Significance of soft skills in career development. Retrieved January 14, 2021 from https://www.intechopen.com/books/career-development-and-job-satisfaction/significance-of-soft-skills-in-careerdevelopment. DOI: 10.5772/intechopen.89935

Tsey, K., Liu, S.M., \& Heyeres, M. (2018). Developing soft skills: Exploring the feasibility of an Australian well-being program for health managers and leaders in Timor-Leste. SAGE Open, 8(4), DOI: 10.1177/2158244018811404

Vasanthakumari, S. (2019). Soft skills and its application in work place. World Journal of Advanced Research and Reviews, 03(02), 66-72. DOI: 10.30574/wjarr.2019.3.2.0057

Wats, M. \& Wats, R.K. (2009). Developing soft skills in students. The International Journal of Learning Annual Review, 15(12):1-10.

Wheeler, R. (2016). Soft skills - The importance of cultivating emotional intelligence. American Association of Law Libraries (AALL) Spectrum, 20, 28-31.

World Bank. (2014). STEP skills measurement surveys: Innovative tools for assessing skills (English). Social protection and labor discussion paper no. 1421. Washington, DC: World Bank Group. Assessed on December 7, 2019 from http://documents.worldbank.org/curated/en/516741468178736065/STEP-skills-measurement-surveys-innovative-toolsfor-assessing-skills

World Bank. (2013). STEP skills measurement employer survey 2012 (wave 2). Georgia, 2012 - 2013. Assessed on December 7, 2019 from https://microdata.worldbank.org/index.php/catalog/2565 